\title{
Deskripsi Efisiensi Agribisnis Usahatani Kentang pada Alternatif Kombinasi Input Produksi di Desa Kaban Kecamatan Kabanjahe Kabupaten Karo
}

\author{
Stefanus Deras dan Helviani Sinulingga \\ Prodi Agribisnis, Fakultas Pertanian, Unika St. Thomas \\ Email : agribisnisfapertaunika@gmail.com
}

\begin{abstract}
Abstrak
Agribisnis kentang penting sebagai sumber pendapatan petani, kebutuhan ekspor, dan bahan baku industri. Produksi ditentukan oleh jenis, kualitas, dan kuan-titas input produksi, juga kombinasi in-put yang digunakan. Harga input dan harga produksi menentukan efsiensi dal-am agribsinis kentang. Penelitian ini bertujuan untuk mendeskripsikan tingkat efisiensi penggunaan input produksi pa-da kondisi riil usahatani, dan kombinasi alaternatif yang membuat sesuatu input tertentu dapat memberi nilai efisiensi yang rasional daripada input yang lain-nya. Hasil analisis data memperlihatkan input produksi yang penggunaannya sudah rasional dalam kondisi riil usaha-tani hanyalah pupuk kandang, pupuk hidro dan pupuk paten kali, dengan nilai elastisitas produksi $(1<$ Ep < 0). Melalui metode apriori terhadap informasi, di-ketahui bahwa input produksi bibit mem-beri nilai efisiensi teknis yang rasional pada: kombinasi I (bibit, pupuk kandang, pupuk cantik, pupuk hidro, pupuk paten kali, X-TraNil, dan tenaga kerja);.kombi-nasi IV (bibit, pupuk kandang, pupuk hidro, pupuk paten kali, X-TtraNil, dan tenaga kerja); kombinasi V (bibit, pupuk kandang, pupuk hidro, X-TtraNil, dan tenaga kerja). Input produksi pupuk kandang dan pupuk paten kali menyum-bang nilai efisiensi yang rasional pada kombinasi I. Pestisida mantab menyum-bang nilai efisiensi yang rasional pada kombinasi I. Berbagai kombinasi itu menyumbang nilai efisiensi teknis de-ngan elastisitas produksi $(1<$ Ep < 0$)$. Dari segi harga, penggunaan input pro-duksi dengan berbagai alternative dan kondisi riil di lapangan semuanya pada kondisi yang tidak rasional, dengan efisiensi $(\mathrm{k})>1$.
\end{abstract}

Kata kunci: input produksi, efisiensi, alternative kombinasi input

\begin{abstract}
Potato agribusiness is important as a source of income for farmers, export needs, and industrial raw materials. Production is determined by the type, quality, and quantity of production inputs, as well as the combination of inputs used. Input prices and production prices determine efficiency in potato agribusiness. This study aims to describe the level of efficiency in the use of production inputs in real conditions of farming, and the combination of alternative tools that make certain inputs can provide rational efficiency values than other inputs. The results of data analysis show that production inputs whose use is rational in real farming conditions are only manure, hydro fertilizer and paten kali fertilizer, with production elasticity values $(1<E p<0)$. Through the apriori method of information, it is known that the input of seed production gives a rational technical efficiency value in: combination I (seeds, manure, cantik fertilizer, hydro fertilizer, paten kali fertilizer, $X$ TraNil, and labor); combination IV (seeds, manure, hydro fertilizer, paten kali fertilizer, X-traNil, and labor); combi-nation V (seeds, manure, hydro fertilizer, X-traNil, and labor). Production inputs of manure and paten kali fertilizer contributed to the rational efficiency value in combination I. Mantab pesti-cides contributed rational efficiency values to combination I. The various combinations contributed to the tech-nical efficiency value with production elasticity $(1<E p<0)$. In terms of price, the use of production inputs with various alternatives and real conditions in the field are all in irrational conditions, with efficiency $(k)>1$.
\end{abstract}

Keywords: production input, efficiency, alternative input combination

\section{PENDAHULUAN}

\section{A. Latar Belakang}

Agribisnis kentang penting seba-gai sumber pendapatan petani, kebutuh-an ekspor, dan bahan baku industri. Tingginya kandungan karbohidrat men-jadikan kentang sebagai bahan pangan menggantikan bahan pangan penghasil kabohidrat seperti beras, gandum dan jagung [1]. Selain itu banyaknya industri pengolahan yang memanfaatkan kentang sebagai bahan baku untuk olahan keripik kentang, kentang goreng (french fries) dan aneka macam makanan ringan.
Permintaan kentang dari tahun ke tahun cenderung meningkat seiring dengan bertambahnya penduduk, peningkatan pendapatan, perubahan gaya hidup mas-yarakat yang menyukai makan di restoran (fast food) dan berkembangnya industri pengolahan kentang [2]. Selama kurun waktu tahun 2015-2019, produk-tivitas kentang secara nasional yang mencapai 17,97 ton, tingkat propinsi 16,608 ton, kabupaten 17 ton, dan ting-kat kecamatan 19,08 ton, ternyata masih jauh di bawah hasil potensial pada ting-kat Balai Benih Induk Hortikultura Kuta Gadung Berastagi yang mencapai 53 ton [3], [4], 
dan [5]. Rendahnya produkti-vitas kentang antara lain karena peng-gunaan benih kentang yang kurang bah-kan tidak berkualitas. Hal ini disebabkan kurangnya ketersediaan bibit kentang berkualitas pada tingkat usahatani. Hingga saat ini, pemenuhuan kebutuhan bibit kentang bersertifikat secara nasional hanya 10 persen, sedangkan sisanya menggunakan bibit hasil seleksi sendiri yang berkualitas rendah [6]. Sebab lain rendahnya produktivitas kentang adalah kombinasi penggunaan sarana produksi yang kurang bahkan tidak rasional. Belum lagi harga sarana produksi dan harga produksi yang tidak sepadan dengan jumlah produksi yang dihasilkan menyebabkan kurang efisien-nya agribisnis usahatani kentang. Pertemuan harga input produksi, jumlah produksi, dan harga jual produksi akan menentukan besar kecilnya efisiensi ekonomi agribisnis kentang. Atas dasar ini, perlu diteliti: (1) Bagaimana tingkat efisiensi agribisnis kentang pada kombi-nasi input produksi yang riil digunakan petani dalam usahatani. (2) Melalui me-tode apriori, pada alternative kombinasi input produksi apa yang membuat sesu-atu input tertentu dapat memberi nilai efisiensi yang rasional daripada input yang lainnya?

\section{KERANGKA TEORITIS}

\section{A. Konsepsi Produksi}

Menurut [7\}, dalam menunjang keberhasilan agribisnis pada tingkat agroindustri dan pemasaran maka ter-sedianya bahan baku pertanian secra kontinu dalam jumlah yang tepat sangat diperlukan. Produksi ini dipengaruhi oleh berbagai factor, antara lain: macam komoditi (X1), luas lahan (2), tenaga kerja (X3), modal (X4), managemen (X5), iklim (X6), dan factor social eko-nomi produsen (X7). Secara matematis, pernyataan ini dapat dituliskan sebagai berikut: $Y=\mathrm{f}(\mathrm{X} 1, \mathrm{X} 2, \mathrm{X} 3, \mathrm{X} 4, \mathrm{X} 5, \mathrm{X} 6 . \mathrm{X} 7)$. Salah satu persamaan fungsi produksi yang banyak digunakan dalam penelitian adalah Fungsi produksi Cobb-Douglass. Persamaan ini melibatkan dua atau lebih variabel. Secara matematik, fungsi produksi Cobb-Douglass dapat ditulis-kan sebagai berikut :

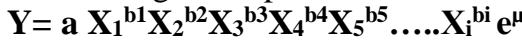

Untuk memudahkan pendugaan terhadap persamaan tersebut maka harus diubah menjadi bentuk linear berganda dengan cara melogaritmakan persamaan tersebut. Logaritme dari persamaan diatas adalah:

\section{$\log Y=\log _{0}+b_{1} \log X_{1}+b_{2} \log X_{2}+$ $b_{3} \log X_{3}+b_{4} \log X_{4}+b_{5} \log X_{5}$ $+\ldots . .+b_{i} \log b_{i}+\mu$}

\section{B. Konsepsi Efisiensi}

Efisiensi adalah suatu ukuran relatif dari beberapa input yang diguna-kan untuk menghasilkan output tertentu. Konsep ini mengandung tiga pengertian yaitu efisiensi teknis, efisiensi harga dan efisiensi ekonomi. Suatu usahatani di-katakan efisien secara teknis, jika usaha-tani tersebut menghasilkan jumlah pro-duksi yang lebih banyak daripada usaha-tani lainnya, dengan menggunakan fak-tor produksi yang sama atau suatu usahatani menghasilkan sejumlah produksi tertentu dengan menggunakan fak-tor produksi lebih sedikit dari pada usaha tani lainnya. Efisiensi harga dapat ter-capai jika petani dapat memperoleh ke-untungan yang besar dari usahataninya. Suatu usahatani dikatakan mencapai efi-siensi ekonomis apabila telah memaksi-mumkan keuntungannya. Keuntungan maksimum akan diperoleh jika petani menggunakan pilihan kombinasi faktor-faktor produksi yang optimum. Pada saat keuntungan maksimum telah dicapai, berarti faktor-faktor produksi telah di-gunakan secara efisien [8]. Menurut [9] jika petani mampu meningkatkan pro-duksi tertinggi dengan menekan biaya produksi seminim mungkin tetapi men-jual hasil produksi pada harga tertinggi maka petani tersebut telah melakukan efisiensi teknis dengan efisiensi harga secara bersamaan disebut dengan efisi-ensi ekonomis. Efisiensi penggunaan sa-rana akan tercapai jika nilai produk mar-ginal (NPM) untuk suatu sarana sama dengan harga sarana $\left(\mathrm{P}_{\mathrm{x}}\right)$ tersebut, atau secara matematis dapat ditulis dengan rumus: $\mathrm{NPM}_{\mathrm{x}}=\mathrm{P}_{\mathrm{x}}$ atau $\frac{\mathrm{NPM} \mathrm{x}}{\mathrm{Px}_{\mathrm{x}}}=1$.

Efisiensi harga atau efisiensi alo-katif berhubungan dengan keberhasilan pengusaha dalam mencapai keuntungan maksimum. Hal ini dapat dicapai apabila nilai produk marginal (NPM) sama dengan input atau marginal value pro-duct (MVP) sama dengan marginal input cost (MIC), secara matematis dapat di-tulis: $\mathrm{MVP}_{\mathrm{xi}}=\mathrm{MP}_{\mathrm{xi}} \cdot \mathrm{P}_{\mathrm{y}}$; dimana $\mathrm{P}_{\mathrm{xi}}=\frac{\partial y}{\partial X \mathrm{i}}=\mathrm{b}_{\mathrm{i}} \cdot \frac{Y}{X i}$. Dalam hal ini $\mathrm{b}_{\mathrm{i}}=$ koefisien regresi untuk input ke-i, de-ngan demikian $: \mathrm{MVP}_{\mathrm{xi}}=\mathrm{bi} \cdot \frac{\mathrm{Y}, \mathrm{Py}}{\mathrm{Xi}}$. Apabila harga faktor

produksi yang digunakan adalah $\mathrm{P}_{\mathrm{xi}}$ maka secara matematis efisiensi harga tercapai pada saat: $\mathrm{MVP}_{\mathrm{xi}}$ $=\mathrm{P}_{\mathrm{xi}}$. Dengan subsitusi persamaan diperoleh :

$$
\begin{aligned}
& \text { bi. } \bar{Y} \cdot \overline{P_{Y}} / \overline{X_{1}}=P_{x i} \text { atau } \frac{\text { bi }, \bar{Y} \cdot \overline{P_{y}}}{\overline{X_{1}} \overline{P_{x}}}=1 \\
& \text { dimana, } \mathrm{k}_{\mathrm{i}}=\frac{\overline{\mathrm{Y}} \cdot \overline{\mathrm{Py}_{\mathrm{y}}}}{\overline{\mathrm{X}} \cdot \mathrm{P}_{\mathrm{j}}} \cdot \text { bi sehingga, } \mathrm{ki}=1 \text {. }
\end{aligned}
$$

Hasil penelitian sebelumnya antara lain [10] merekomendasikan kebutuhan bibit kentang sebanyak $1.2-1.5$ ton//ha. Rekomendasi pupuk (per hektar) urea $200 \mathrm{~kg}$, SP-36 $100-100 \mathrm{~kg}$, ZA $150 \mathrm{~kg}$, NPK $100 \mathrm{~kg}$. Rekomendasi alternative adalah pupuk anorganik dalam jumlah yang relatif banyak; misalnya, pemupuk-an dasar Urea $200 \mathrm{~kg}$, SP36 200 $\mathrm{kg}$, KCL $75 \mathrm{~kg}$, POC 1-2 botol per $1000 \mathrm{~m},{ }^{2}$ pupuk kandang 5-6 ton, Susulan I SP36 $250 \mathrm{~kg}$, KCL 150 $\mathrm{kg}$. Selanjutnya pemu-pukan susukan II setelah berumur 45 hari sbb: Urea $150 \mathrm{~kg}$ dan KCL $75 \mathrm{~kg}$. 
Hal lain yang sangat penting dapat merangsang produksi ialah harga jual. Tinggi rendahnya harga kentang dipe-ngaruhi oleh musim panen dan grading. Hasil penelitian [11] menunjukkan bah-wa produksi kentang 16.015 $\mathrm{kg} / \mathrm{ha}$, biaya total $\mathrm{Rp} 35.650 .715$ /ha, penerimaan Rp 72.467.875/ha, dan keuntungan Rp 36.817.160/ ha. Analisis efisiensi me-nunjukkan bahwa perbandingan antara nilai produk marjinal (NPM) dan biaya korbanan marjinal (BKM) baik lahan, pupuk organik, mau-pun pestisida lebih dari satu. Hal ini berarti penggunaan faktor produksi tersebut belum efisien. Keuntungan usahatani kentang cukup besar melalui penambahan lahan, pupuk organik, dan pestisida. Penggunaan ketiga faktor produksi ini masih dapat ditingkatkan sampai batas perbandingan nilai produk marjinal dan biaya korbanan marjinal faktor produksi sama dengan satu.

Hasil penelitian [12], menunjuk-kan efisiensi agribisnis kentang G4 ber-sertifikasi sebesar 0,31 lebih kecil dari efisiensi agribisnis kentang G4 non serti-fikasi sebesar 0,43. Data memperlihat-kan jumlah pemakaian sarana produksi dan tenaga kerja melebihi rekomendasi, berimplikasi pada berkurangnya efisi-ensi. Kedua angka efisiensi yang diukur dengan $\mathrm{B} / \mathrm{C}$ ratio lebih kecil daripada efisiensi agribisnis kentang G4 berserti-fikasi dengan rekomendasi pemakaian pupuk anorganik tunggal sebesar 2,22 dan pupuk majemuk sebesar 1,998.

Hasil penelitian [13], dari segi skala usahatani menunjukkan bahwa kondisi usahatani kentang dengan meng-gunakan seluruh input produksi berada pada tahap I, dengan Ep $=1,025$. Ini bearti masih memungkinkan jika penam-bahan faktor produksi akan meningkat-kan produksi. Jika dilihat dari masing-masing penggunaan faktor produksi, maka semua pada tahap II. Pada tahap ini menunjukkan kondisi decreasing rate. Koefisien regresi ini juga memper-lihatkan elastisitas produksi kurang dari satu atau Ep $<1$. Kondisi elastisitas lebih kecil dari satu menunjukkan bahwa proses produksi berada pada tahap dua, artinya marginal product masih positif, dan rata-rata produksi menurun, pening-katan produksi masih dapat diharapkan. Hasil estimasi efisi-ensi teknis dengan menggunakan $n=200$, didapatkan efisi-ensi teknis adalah 0,886. Perhitungan efisiensi ekonomis menunjukkan bahwa penggunaan input (faktor produksi) yang dapat dtingkatkan adalah luas lahan dan pemakaian bibit. Input (faktor produksi) yang lain harus dikurangi pengguna-annya karena sudah tidak ekonomis, yaitu untuk pemakaian pupuk kimia, insektisida, pupuk kandang, tenaga kerja, dan fungisida.

\section{METODE PENELITIAN}

Penelitian ini merupakan studi kasus di Desa Kaban, ditetapkan secara sengaja tanpa pertimbangan represen-tatip terhadap desa-desa lain. Ada fenomena yang unik di desa ini yakni menggunakan beragam sarana produksi yang menyimpang dari rekomendasi sehingga diragukan efektivitas dan efisiensinya secara ekonomi. Penelitian ini berbentuk survei dan observasi berlangsung selama Februari sd April 2021, pada 35 rumah tangga usahatani kentang varietas Granola 3 (G3) sebagai populasi, sekaligus menjadi responden penelitian. Data sekunder dicatat dari Dinas Perdagangan Kabupaten Tanah Karo, terutama data produksi total kentang yang dihasilkan di kecamatan, khususnya di Desa Kaban. Data primer dikumpulkan dari rumah tangga usahatani melalui survey (observasi dan wa-wancara terstruktur bersifat terbuka).

Penelitian ini bersifat deskriptif tanpa pengujian hipotesis. Mendeskripsi-kan tampilan nilai efisiensi agribisnis kentang pada kondisi riil usahatani dan kondisi alternative kombinasi input produksi yang digunakan. Angka efisi-ensi agribisnis dihitung pertama-tama di-lakukan dengan persamaan fungsi pro-duksi Cobb Douglass untuk mengetahui efisiensi teknis, dengan rumus $Y=\mathbf{a}$ $\mathbf{X}_{\mathbf{1}}{ }^{\mathbf{b}} \mathbf{X}_{\mathbf{2}}{ }^{\mathbf{b} 2} \mathbf{X}_{\mathbf{3}}{ }^{\mathbf{b} 3} \mathbf{X}_{\mathbf{4}}{ }^{\mathbf{b} 4} \mathbf{X}_{5}{ }^{\mathbf{b 5}} \ldots . . \mathbf{X}_{\mathbf{i}}^{\mathbf{b i}} \mathbf{e}^{\boldsymbol{\mu}}$, yang dapat diubah menjadi bentuk linear berganda dengan cara melogaritmakan persamaan tersebut menjadi $\log \mathbf{Y}$ $=\log b_{0}+b_{1} \log X_{1}+b_{2} \log X_{2}+b_{3 \log X 3}+\ldots+b_{i} \log b_{i}+$ $\boldsymbol{\mu}$. Selanjutnya menghitung efisiensi harga dengan persamaan matematika berkut: $\frac{\mathrm{bi}, \overline{\mathrm{Y}} \cdot \overline{\mathrm{Py}_{\mathrm{y}}}}{\overline{\mathrm{X}_{1}} \overline{\mathrm{P}_{\mathrm{X}}}}=1 ; \mathrm{k}_{\mathrm{i}}=$ $\frac{\bar{Y} \cdot \overline{\mathrm{Py}}}{\overline{\mathrm{X}} \cdot \mathrm{Pxj}}, \mathrm{bi}$

Penentuan alternatif kombinasi input di-lakukan setelah diketahui adanya indi-kasi terjadi multikolinearity di antara va-riabel eksplanatory. Di sini diterapkan metode apriori terhadap informasi, mem-buang pasangan variabel eksplanatori yang memiliki nilai korelasi hampir sem-purna di antara 0,8 dan 0,9 [14].

\section{HASIL PENELITIAN DAN PEMBAHASAN}

Hasil penelitian memperlihatkan adanya sepuluh jenis input produksi yang digunakan petani dalam usaha me-ningkatkan produksi kentang. Sarana produksi itu adalah bibit, pupuk kan-dang, pupuk cantik, pupuk hidro, pupuk paten kali butir, fungisida mantab, X-TraNil, insektisida abacel, curacron, dan unsur tenaga kerja.

Hasil perhitungan koefisien reg-resi dan efisiensi harga (ki) menunjuk-kan penggunaan faktor produksi yang belum efisien $(\mathrm{ki}<1)$ dan bahkan tidak efisien (ki > 1), sebagaimana disajikan berturut-turut pada Table 1 dan Tabel 2 .

Dari Tabel 1, terlihat bahwa dalam kon-disi riil usahatani, variable pupuk kan-dang, pupuk hidro, dan pupuk paten kali butir berada pada penggunaan yang rasi-onal namun masih harus ditingkatkan, dengan nilai elastisitas $(1<$ Ep $<0)$. Penggunaan 
bibit pada kondisi riil tidak rasional (belum efisien) dengan Ep $(1,25)>1$, karenannya masih dapat ditingkatkan terutama kualitas bibit. Input variable lain juga pada penggunaan yang tidak rasional dengan $((1<$ Ep $<0)$, meliputi pupuk cantik, pestisida mantab, X-Ttra-Nil, abacel, curacon, dan tenaga kerja. Dengan mencoba beberapa altern-ative kombinasi, dari Tabel 1 terlihat kombinasi input (pupuk kandang, pupuk

hidro, pupuk paten kali, pestisida mantab dan tenaga kerja) sudah rasional dengan nilai elastisitas produksi $(1<$ Ep < 0), meski masih harus ditingkatkan. Semen-tara itu, penggunaan insektisida X-Tra-Nil, abacel, dan curacron pada kondisi tidak rasional dengan nilai elastisitas $<0$.

Tabel 1. Keragaan Nilai Efisiensi Teknis Agribisnis Usahatani Kentang.

\begin{tabular}{|c|c|c|c|c|c|c|}
\hline \multirow{2}{*}{$\begin{array}{l}\text { Kombin } \\
\text { asi Input } \\
\text { Produksi } \\
\text { (Xi) }\end{array}$} & \multicolumn{6}{|c|}{$\begin{array}{l}\text { Efisiensi Teknis pada Beberapa } \\
\text { Alternatif Kombinasi Input }\end{array}$} \\
\hline & $\begin{array}{c}\text { Kond } \\
\text { isi } \\
\text { Rill } \\
\end{array}$ & I & II & III & IV & $\mathrm{V}$ \\
\hline $\begin{array}{l}\text { BIBIT } \\
(\mathrm{X} 1)\end{array}$ & 1,25 & $x$ & $X$ & $\begin{array}{l}0,9 \\
3^{1)}\end{array}$ & $\begin{array}{l}0,8 \\
9^{2)}\end{array}$ & $\begin{array}{l}0,9 \\
8^{2)}\end{array}$ \\
\hline $\begin{array}{l}\text { P.KAND } \\
\text { ANG } \\
(\mathrm{X} 2)\end{array}$ & $\begin{array}{c}0,18^{1} \\
1\end{array}$ & $\begin{array}{l}0,3 \\
9^{11} \\
\end{array}$ & $\begin{array}{c}0,3 \\
2^{1} \\
\end{array}$ & $\begin{array}{l}0,0 \\
6^{1)}\end{array}$ & $\begin{array}{l}0,0 \\
6^{1)}\end{array}$ & $\begin{array}{l}0,0 \\
1^{1)}\end{array}$ \\
\hline $\begin{array}{l}\text { P.CANTI } \\
\mathrm{K}(\mathrm{X} 3)\end{array}$ & $-0,17$ & $x$ & $x$ & $\begin{array}{l}0,02 \\
1)\end{array}$ & $x$ & $X$ \\
\hline $\begin{array}{l}\text { P.HIDRO } \\
(X 4)\end{array}$ & $\begin{array}{c}0,11^{1} \\
1\end{array}$ & $\begin{array}{l}0,0 \\
7^{1)} \\
\end{array}$ & $\begin{array}{l}0,0 \\
6^{1)} \\
\end{array}$ & $\begin{array}{l}0,15 \\
1)\end{array}$ & $\begin{array}{c}0,13 \\
1)\end{array}$ & $\begin{array}{c}0,12 \\
1)\end{array}$ \\
\hline $\begin{array}{l}\text { P.PATEN } \\
\text { KALI ( } \\
\times 5)\end{array}$ & $\begin{array}{c}0,31^{1} \\
,\end{array}$ & $\begin{array}{l}0,3 \\
8^{11} \\
\end{array}$ & $\begin{array}{l}0,3 \\
5^{1)}\end{array}$ & $\begin{array}{c}0,13 \\
1)\end{array}$ & $\begin{array}{l}0,06 \\
1)\end{array}$ & $X$ \\
\hline $\begin{array}{l}\text { PES } \\
\text { MANTE } \\
B(X 6)\end{array}$ & $-0,10$ & $\begin{array}{l}0,2 \\
6^{1)}\end{array}$ & $\begin{array}{l}0,1 \\
6^{1)}\end{array}$ & $\begin{array}{c}- \\
0,05\end{array}$ & $\mathrm{x}$ & $\mathrm{X}$ \\
\hline $\begin{array}{l}\text { XTRA- } \\
\text { NIL (X7) }\end{array}$ & $-0,16$ & $\begin{array}{c}- \\
0,0 \\
3\end{array}$ & $\mathrm{X}$ & $\begin{array}{c}- \\
0,18\end{array}$ & $\begin{array}{c}- \\
0,15\end{array}$ & $\begin{array}{l}0,01 \\
1)\end{array}$ \\
\hline $\begin{array}{l}\text { ABACEL } \\
(\mathrm{X} 8)\end{array}$ & $-0,08$ & $\begin{array}{c}- \\
0,0 \\
7\end{array}$ & $\mathrm{X}$ & $x$ & & $X$ \\
\hline $\begin{array}{l}\text { CURACR } \\
\text { ON (X9) }\end{array}$ & $-0,08$ & $\begin{array}{c}- \\
0,0 \\
8\end{array}$ & $X$ & $\mathrm{x}$ & & $X$ \\
\hline
\end{tabular}

\begin{tabular}{|l|c|c|c|c|c|c|}
\hline $\begin{array}{l}\text { T.KERJA } \\
(\mathrm{X} 10)\end{array}$ & $-0,05$ & 0,0 & 0,0 & 0,03 & 0,01 & 0,13 \\
$4^{1)}$ & $5^{1)}$ & $1)$ & $1)$ & $1)$ \\
\hline
\end{tabular}

Keterangan:1)penggunaan yang rasional namun belum optimum,

x) tidak menggunakan

Secara ringkas dapat diuraikan: pada alternative I, input produksi (bibit, pupuk kandang, dan pupuk hidro) sudah mencapai efisiensi yang hampir sempurna pada semua alternative kombi-nasi. Pada alternative II, terlihat secara teknis semua input yang digunakan (pupuk hidro, pupuk paten kali, pestisida manteb, dan tenaga kerja) sudah rasional walau masih harus ditingkatkan, dengan nilai elastisitas produksi $(1<$ Ep < 0$)$. Pada alternative III, terlihat secara teknis hanya variable input bibit yang rasional dengan nilai elastisitas produksi sebesar 0,93. Variabel input lainnya (pupuk kandang, pupuk cantik, pupuk hidro, pupuk paten kali, dan tenaga kerja) wa-lau beroperasi pada kondisi yang rasi-onal, namun kontribusinya terhadap pro-duksi masih minim. Berbeda dengan variable input pestisida mantab dan X-TraNil, penggunaaannya tidak rasional (berlebihan) menyebabkan menurunnya produksi kentang. Pada alternative IV, terlihat secara teknis kombinasi input produksi (bibit, pupuk kandang, pupuk hidro, pupuk paten kali, dan tenaga kerja) kecuali pestisida XTraNil, semua nya berada pada penggunaan yang rasi-onal meskipun masih sangat minim dan belum efisien sehingga harus ditingkat-kan, dicirikan oleh nilai elastisitas $(1<\mathrm{Ep}<0)$. Pada alternative V, terlihat secara teknis penggunaan bibit mencapai tingkat yang efisiensi, dengan elastisitas sebesar 0,98. Kombinasi input (produksi pupuk kandang, pupuk hidro, pestisida X-TraNil, dan tenaga kerja) walau semuanya pada penggunaan yang rasional namun masih sangat minim dan belum efisien sehingga harus ditingkat-kan. Ini dicirikan oleh nilai $(1<\mathrm{Ep}<0)$.

Ditinjau dari segi efisiensi harga (Tabel 2), kombinasi input pada kondisi riil usahatani memperlihatkan penggunaan input produksi (bibit, pupuk. kandang, pupuk hidro, dan pupuk paten kali) yang tidak efisien, dengan nilai. ki $>1$. Input produksi (pupuk cantik, pestisida mantab, XTtraNil, abacel, curacron, dan

Tabel 2. Keragaan Nilai Efisiensi Harga Agribisnis Kentang

\begin{tabular}{|c|c|c|c|c|c|c|}
\hline \multirow{2}{*}{$\begin{array}{c}\text { Kombinasi Input } \\
\text { Produksi (Xi) }\end{array}$} & \multicolumn{6}{|c|}{ Efisiensi Harga pada Beberapa Alternatif Kombinasi Input } \\
\cline { 2 - 7 } & Kondisi Rill Usahatani & $\mathrm{I}$ & $\mathrm{II}$ & $\mathrm{III}$ & $\mathrm{IV}$ & $\mathrm{V}$ \\
\hline BIBIT (X1) & $12,78^{* *}$ & $\mathrm{X}$ & $\mathrm{X}$ & $9,54^{* *}$ & $9,16^{* *}$ & $10,01^{* *}$ \\
\hline & & & 64,04 & & & \\
P.KANDANG (X2) & $36,36^{* *}$ & $79,99^{* *}$ & $* * *$ & $11,92^{* *}$ & $12,73^{* *}$ & $1,82^{* *}$ \\
\hline P.CANTIK (X3) & $-7,12^{*}$ & $\mathrm{X}$ & $\mathrm{X}$ & 0,95 & $\mathrm{X}$ & $\mathrm{X}$ \\
\hline P.HIDRO (X4) & $3,02^{* *}$ & $1,86^{* *}$ & $1,67^{* * *}$ & $4,09^{* *}$ & $3,75^{* *}$ & $3,38^{* *}$ \\
\hline P.PATEN KALI (X5) & $10,14^{* *}$ & $12,73-$ & $11,60^{* * *}$ & $4,31^{* *}$ & $1,86^{* *}-$ & $\mathrm{X}$ \\
\hline
\end{tabular}




\begin{tabular}{|c|c|c|c|c|c|c|}
\hline \multirow{2}{*}{$\begin{array}{l}\text { Kombinasi Input } \\
\text { Produksi (Xi) }\end{array}$} & \multicolumn{6}{|c|}{ Efisiensi Harga pada Beberapa Alternatif Kombinasi Input } \\
\cline { 2 - 7 } & Kondisi Rill Usahatani & I & II & III & IV & V \\
\hline PES MANTAB (X6) & $-16,22^{*}$ & $42,37^{* *}-$ & $26,48^{* * *}$ & $-4,27^{*}$ & $\mathrm{X}$ & $\mathrm{X}$ \\
\hline X-TRA-NIL (X7) & $-13,12^{*}$ & $2,58^{*}-$ & $\mathrm{X}$ & $-15,53^{*}$ & $\mathrm{X}$ & $11,20^{* *}$ \\
\hline ABACEL (X8) & $-6,45^{*}$ & $5,86^{*}$ & $\mathrm{X}$ & $\mathrm{X}$ & $12,39^{*}$ & $\mathrm{X}$ \\
\hline CURACRON (X9) & $-11,07^{*}$ & $10,27^{*}$ & $\mathrm{X}$ & $\mathrm{X}$ & $\mathrm{X}$ & $\mathrm{X}$ \\
\hline T.KERJA (X10) & $-0,64^{*}$ & $0,47^{*}$ & $0,65^{* *}$ & $0,33^{*}$ & $0,17^{*}$ & $0,18^{*}$ \\
\hline
\end{tabular}

Keterangan: *) tidak efisien, $\mathrm{ki}<1$,

**) belum efisien, ki > 1 ,

$\mathrm{x})$ tidak menggunakan

tenaga kerja) memperlihatkan pengguna-an yang tidak efisiesn, dengan nilai ki $<1$. Dari segi harga, dalam kondisi usaha-tani yang riil, input tenaga kerja mem-perlihatkan penggunaan yang tidak rasi-onal secara teknis maupun secara harga, ditunjukan oleh nilai elastisitas $<0$, dan nilai efisiensi harga $(\mathrm{ki})<1$, bahkan mencapai angka minus $(\mathrm{ki}<0)$. Pada berbagai alternative kombinasi input, variable tenaga kerja memperlihatkan penggunaan yang rasional walau belum efisiensi baik secara teknis maupun seca-ra harga. Penggunaan input yang lain, kecuali pupuk cantik, tidak efisien pada berbagai alternative kombinasi input, dengan nilai efisiensi (ki) $>1$. Ditinjau dari segi efisiensi harga, kombinasi input pada alternative I, memperlihatkan peng-gunaan input (kandang, pupuk paten kali, pestisida mantab) sudah rasional walau belum mencapai tingkat yang efi-sien, dan karenanya masih harus diting-katkan, dicirikan oleh nilai efisiensi $(\mathrm{ki})<1$. Sementara itu, penggunaan input (pupuk hidro, X-TraNil, abacel, cura-cron, dan tenaga kerja) berlebihan hing-ga menjadi tidak efisien. Dari segi harga, kombinasi pada alternative II sudah tidak efisien, dengan nilai efisiensi $(\mathrm{ki})>1$. Variabel input tenaga kerja belum mem-perlihatkan kondisi yang efisien, karena-nya masih harus ditingkatkan lagi. Pada alternative III, dari segi harga, kombinasi tersebut, sebagian berada pada kondisi pemakaian yang tidak efisien dengan nilai efisiensi (ki) > 1 , meliputi variable bibit, pupuk kandang, pupuk hidro, pupuk paten kali. Variabel input pupuk cantik mencapai tingkat yang efisien pada kombinasi ini, dengan nilai (ki) 0,95 mendekati $\mathrm{ki}=1$. Variabel input (pupuk manteb dan X-TraNil) memper-lihatkan inefisiensi usaha yang sangat tinggi dengan nilai efisiensi $((\mathrm{ki})<1$, bahkan minus $(\mathrm{ki}<0)$ akibat pengaruh buruk variable tersebut terhadap pro-duksi. Pada alternative IV, dari segi harga, kombinasi input produksi tersebut kecuali input tenaga kerja, semuanya berada pada kondisi yang tidak efisien, ditunjukkan oleh nilai efisiensi (ki) $>1$. Koefisien (ki) variable tenaga kerja $<1$, menunjukkan penggunaan yang belum efisien, karenanya masih harus ditingkatkan pengelolaannya. Pada alternative V, dari segi harga, kombinasi input produksi tersebut kecuali input tenaga kerja, semuanya berada pada kondisi yang tidak efisien, ditunjukkan oleh nilai efisiensi (ki) $>1$. Koefisien (ki) variable tenaga kerja $<1$, menunjukkan penggunaan yang belum efisien, dan masih dapat ditingkatkan..

Penggunaan input produksi pada kondisi riil usahatani dan pada kondisi alternative kombinasi input, yang semuanya dari segi harga memperlihatkan kondisi yang tidak rasional $(\mathrm{k}>1)$. mengindikasikan bahwa: (1) harga input produksi yang tinggi berakibat pada penggunaan input produksi yang mini-mum sehingga produksi menurun. (2) Produksi yang rendah dengan harga produksi yang juga rendah tidak mampu mendongkrak nilai efisiensi. Efisiensi harga (k) yang bernilai > 1 menunjuk-kan bahwa penggunaan input produksi yang tidak saja masih sangat minim walaupun harga input relative stabil, namun pemakaian yang sedikit itu tidak mampu menaikkan produksi. Produksi yang sedikit pada harga jual yang rela-tive stabil tidak mampu meningkatkan nilai efisiensi ke arah yang maksimum $(\mathrm{k}=1)$..

\section{KESIMPULAN DAN SARAN}

A. Kesimpulan

1. Penggunaan input produksi dengan kombinasi alternatif I, II, dan III, dimungkinkan secara teknis dengan nilai efisiensi mendekati 1 . Kombi-nasi alternative IV juga sangat dimungkinkan untuk digunakan dalam usahatani kentang, nilai elastisitas produksi $(1<\mathrm{Ep}<0)$.

2. Dari segi harga, penggunaan input produksi dengan berbagai alterna-tive dan kondisi riil di lapangan semuanya pada kondisi yang tidak rasional, dengan efisiensi $(\mathrm{k})>1$.

\section{B. Saran-Saran}

1 Penelitian ini didasarkan pada peng-ukuran kuantitatif, maka disarankan perlunya melakukan penelitian secara kualitatif terkait kualitas input pro-duksi yang digunakan dalam agribis-nis usahatani kentang.

2 Kondisi efisiensi agribisnis pada alter-native kombinasi penggunaan input produksi yang belum bahkan tidak efisien secara teknis dan secara har-ga, disarankan untuk memperbaiki kuantitas dan kualitas penggunaannya sesuai rekomendasi $6 \mathrm{~T}$ (tepat jenis, tepat dosis, tepat sasaran, tepat cara, tepat waktu, dan tepat tempat). 


\section{DAFTAR PUSTAKA}

Ashandi, 2014. Komoditas Kentang. Balai Penelitian Dan Pengem-banganPertanian Hortikultura Lembang.

Santoso. 2008. Hasil Olahan Ken-tang. Penerbit Kanisius. Yogya-karta.

Anonimus. 2019. Statistik Tanaman Hortikultura Sumatera Utara. BPS. Provinsi Sumatera Utara.

2020. Produktivitas Tanaman Kentang Kabupaten Karo Tahun 2015-2019. BPS Kabupaten Karo.

2020. UPT BI Hortikultura Berastagi. Dinas Pertanian Kabupaten Karo, Propinsi Suma-tera Utara.

Afifah, FJ., 2011. Penanganan Penyimpanan Kentang Bibit di Hikmah Farm Pengalengan, Bandung Jawa Barat. Departe-men Agronomi dan Hortikul-tura, Fakultas Pertanian. Institut Per-tanian Bogor.

Soekartawi, 1999. Agribisnis Teori dan Aplikasinya. PT. Raja Gra-findo Persada. Jakarta.

Meiners, 2000. Teori Mikroekonomi Intermediate, Penerjemah Haris Munandar, PT. Raja Grafindo Persada. Jakarta.

Mubiyarto. 1987. Teori Ekonomi Produksi Dengan Pokok Bahasan Analisis Fungsi Cobb Douglas PT. Raja Grafindo Persada. Jakarta.

Setia, 2009. Budidaya Kentang. Penebar Swadaya. Jakarta.

Anny, Hartati. 2011. Tingkat Efisi-ensi Faktor Produksi Pada Usahatani Kentang di Kecamatan Karangreja Jawa Tengah. Jurnal ISSN:1410-0029. Fakultas Pertanian Unsoed.Purwokerto.

Deras Stefanus. 2020. Peningkatan Efisiensi Agribisnis Kentang Melalui Introduksi Bibit Granola 4 Dii Desa Bandar Hinalang Kecamatan Purba Kabupaten

Simalungun, Jurnal Agriust, edisi pertama. Program Studi Agri-bisnis, Fakultas Pertanian Unika St Thomas, Medan.

Tri Widayati, 2014. Analisis Efisi-ensi Penggunaan Faktor Pro-duksi Pada Usahatani Kentang di Kawasan Dieng Jawa Tengah. Jurnal ISBN: 978-602-141192-6. Fakultas Ekonomika dan Bisnis UNTAG, Semarang.

Sudradjat, M. SW. 1984. Mengenal Ekonometrika Pemula. Penerbit Armico. Bandung. 